\title{
IncP-1 R Plasmids Decrease the Serum Resistance and the Virulence of Pseudomonas aeruginosa
}

\author{
By BENGT WRETLIND, ${ }^{*} \dagger$ KARIN BECKER ${ }^{1}$ AND DIETER HAAS ? \\ ${ }^{1}$ Department of Clinical Microbiology, Karolinska Hospital, S-10401 Stockholm, Sweden \\ 2Mikrobiologisches Institut, Eidgenössische Technische Hochschule, CH-8092 Zürich, Switzerland
}

(Received II February 1985; revised 14 May 1985)

Pseudomonas aeruginosa strain PAO1 was compared to PAO1 strains containing an IncP-1 R plasmid (RP1, R68, or R68.45) in an experimental mouse burn infection model. All R plasmids tested caused a 10 - to 400 -fold increase in mean lethal dose $\left(\mathrm{LD}_{5_{0}}\right)$. The decrease in virulence produced by plasmids R68 and R68.45 was significantly greater than the decrease caused by the closely related plasmid RP1. All plasmids also led to an increased sensitivity of strain PAOl to human serum bactericidal activity. Virulence and serum resistance of strain PAOl were restored by curing of the entire plasmid R68.45 but not by deletions in the plasmid's transfer gene regions.

\section{INTRODUCTION}

Bacterial plasmids often carry genes for activities that allow their host to survive in adverse environments or to compete more successfully with other micro-organisms. This selective advantage appears obvious in the case of plasmids that confer resistance to antibiotics. Several plasmids that specify virulence factors have been characterized (Elwell \& Shipley, 1980). Examples of such plasmid-mediated properties are production of toxins and colonization factors (Smith et al., 1983), iron uptake systems (Williams, 1979), and resistance to serum bactericidal activity (Binns et al., 1982). On the other hand, plasmids may be disadvantageous to their hosts. R plasmids have been associated with decreased virulence (Lacey, 1975; Daum et al., 1981), and lower growth rates under nutrient limitation (Klemperer et al., 1979). Gentamicin-resistant Pseudomonas aeruginosa strains are less virulent in experimental rat infections than sensitive strains (Khakoo \& Kluge, 1978), and a recent report has indicated that gentamicin-resistant $P$. aeruginosa strains generally produce only superficial infections in patients in contrast to the more invasive gentamicin-sensitive isolates (Clark et al., 1984).

$P$. aeruginosa strains highly resistant to carbenicillin were first isolated from burns of patients at a Birmingham hospital shortly after the introduction of carbenicillin as a therapeutic agent (Lowbury et al., 1969). This antibiotic resistance was caused by the broad-host-range IncP-1 R plasmids RP1 or R68 (Grinsted et al., 1972). Lowbury et al. (1969) concluded that the carbenicillin-resistant isolates were fully virulent for mice. Here we show that in $P$. aeruginosa strain PAO the plasmids R68, its derivative R68.45, and RP1 lead to a decrease in virulence for mice and an increased susceptibility to human serum bactericidal activity.

\section{METHODS}

Bacterial strains, plasmids and hacteriophages. Pseudomonas aeruginosa strain PAO1 was used as host for the R plasmids RP1, R68 and R68.45 (Grinsted et al., 1972: Stanisich \& Holloway, 1971; Haas \& Holloway, 1976). These plasmids confer resistance to carbenicillin, kanamycin/neomycin and tetracycline. Plasmids pME106 and pME107 were derived from R68.45 ( $\Lambda[\mathrm{Km}$ Tra-1]) and pME140 from R68 ( $\Delta[\mathrm{Km}$ Tra-2]) (Haas \& Riess,

† Present address: Department of Clinical Bacteriology, Danderyd Hospital, S-18288 Danderyd, Sweden. 
1983). PAOlc was a PAOl(R68.45) strain cured of the plasmid. Curing was done by the introduction of the incompatible plasmid pME390 [Cb Tc Kms $\mathrm{m}^{\mathrm{s}} \mathrm{T}$ Sp Rep(ts) Tra IncP-1, a temperature-sensitive RPl derivative carrying Tn7] and subsequent elimination of pME390 by incubation at $43{ }^{\circ} \mathrm{C}$ without antibiotic selection. The cured strain did not carry a plasmid but was resistant to trimethoprim and spectinomycin, indicating that transposon $\mathrm{Tn} 7$ had inserted into the genome. This can happen readily because of a hotspot for $\operatorname{Tn} 7 \mathrm{insertion}$ in the chromosome of strain PAO (Caruso \& Shapiro, 1982). Plasmid pME390 was kindly supplied by John M. Watson, The Australian National University, Canberra City, Australia. All strains were sensitive to phages F116c, E79 and B3c. Their growth rates were tested in nutrient yeast broth (NYB) (Haas \& Holloway, 1976) and their motility was assessed in NYB with $0.6 \%$ agar at $37^{\circ} \mathrm{C}$. Phages were obtained from Bruce W. Holloway, Monash University, Melbourne, Australia.

Sensitivity to serum bactericidal activity. The sensitivity of the plasmid-containing strains to human serum bactericidal activity was tested according to Thomassen \& Demko (1981). The bacteria were grown in Brain Heart Infusion Broth (Difco) and harvested in the exponential phase of growth, washed once in $0 \cdot 15 \mathrm{M}-\mathrm{NaCl}$ with $0.05 \mathrm{M}$ sodium phosphate $\mathrm{pH} 7.2$ (PBS), and diluted to $3.5 \times 10^{8} \mathrm{c}$.f.u. $\mathrm{ml}^{-1}$. The cell suspension was diluted in PBS to a cell density of $3 \times 10^{3}$ c.f.u. $\mathrm{ml}^{-1}$ and mixed with an equal volume of fresh human serum (pooled from three donors) in a test tube. The tubes were incubated at $37^{\circ} \mathrm{C}$ for $1 \mathrm{~h}$. Control tubes containing bacteria and inactivated $\left(56^{\circ} \mathrm{C}\right.$ at $\left.30 \mathrm{~min}\right)$ serum were run in parallel. The serum-sensitive strain PA103 (Liu, 1973) was included as a reference. The number of viable PA103 cells was reduced by $97 \%$ under these conditions.

Mouse burn infection model. The mouse burn model of Stieritz \& Holder (1975) has been described in some detail in previous reports (Pavlovskis \& Wretlind, 1979; Pavlovskis et al., 1983). In short, the backs of female CBA mice (Alab, Stockholm, Sweden) weighing $18-20 \mathrm{~g}$ were shaved, and the mice were anaesthetized with halothane (Hoechst). A template with a $2.5 \times 2.5 \mathrm{~cm}$ opening was placed on the shaved area, which was covered by $0.5 \mathrm{ml}$ $95 \%(\mathrm{v} / \mathrm{v})$ ethanol, and flamed for $10 \mathrm{~s}$. The burn per se was not lethal. A bacterial suspension containing $3.5 \times 10^{8}$ c.f.u. $\mathrm{ml}^{-1}$ was prepared as described above and serial tenfold dilutions of this suspension were prepared in PBS and stored in an ice-bath until use; $0.1 \mathrm{ml}$ of the desired suspension was injected subcutaneously in the burned area immediately after the trauma. To compensate for fluid loss, $0.5 \mathrm{ml} 0.15 \mathrm{M}-\mathrm{NaCl}$ was injected intraperitoneally. Five mice were injected for each dilution, and the mice were observed for $7 \mathrm{~d}$. Strain PAOI was included in all experiments as a reference. Cultivations of bacteria from mice that had succumbed to infection with the plasmid-bearing strains were done in order to determine loss of plasmid in vivo. Samples were taken from the peritoneal and pleural cavities and streaked on blood agar plates (Columbia agar, Difco, supplemented with $5 \%, v / v$, horse blood). Antibiotic sensitivity discs (Biodisk, Solna, Sweden) containing the appropriate antibiotic (kanamycin or carbenicillin) were then placed on the agar plate.

Statistical methods. The mean lethal dose $\left(\mathrm{LD}_{50}\right)$ was calculated by the Spearman-Kärber method as described by Finney (1964). Student's $t$ test was used to compare the $\mathrm{LD}_{50}$ values of different strains.

\section{RESULTS AND DISCUSSION}

Strain PAOl was virulent in the mouse burn infection model. On average, 15 c.f.u. were sufficient to cause a 50\% lethality (Table 1). The plasmids RP1, R68 and R68.45 caused a significant 15-400-fold decrease in virulence (Table 1). The effects of R68 and R68.45 (an R86 derivative with an IS21 duplication; Willetts et al., 1981) were similar whereas RP1 had a less pronounced effect (Table 1). R68 and RP1 are indistinguishable with respect to size, antibiotic resistance determinants and restriction cleavage sites (Burkardt et al., 1979; Currier \& Morgan, 1981) but differ in at least one phenotypic trait: strain PAO1 carrying RP1 propagates the plasmid-specific phage PRR1 whereas strain PAO1 carrying R68 or R68.45 does not (Willetts et al., 1981; D. Haas, unpublished data). Thus, the surface of PAO1 may differ according to the $\mathrm{R}$ plasmid carried and this might conceivably influence the bacterium's survival in an animal. Strain PAO1c, which was cured of the plasmid R68.45, was as virulent as the original strain PAO1 (Table 1). This indicates that the observed decrease in virulence was due to the IncP-1 plasmid itself rather than to a plasmid-induced host mutation.

Strains PAOl and PAOlc were resistant to serum bactericidal activity. By contrast, all plasmid-containing strains were somewhat serum-sensitive (Table 1) and this fact might account, at least in part, for their decreased virulence. Since RP1 and R68/R68.45 had a similar effect on the survival of strain PAO1 in serum there may be additional factors involved in the decreased virulence caused by R68/R68.45.

In a rich medium (NYB) all strains tested had the same doubling time (about $30 \mathrm{~min}$ ) and showed no visible differences in motility or sensitivity to some virulent phages. In the absence of 
Table 1. Virulence and serum sensitivity of $P$. aeruginosa $P A O 1$ with and without IncP-I plasmids

\begin{tabular}{|c|c|c|c|c|c|}
\hline \multirow[b]{2}{*}{ Strain } & \multicolumn{4}{|c|}{ Experimental mouse burn infection } & \multirow[b]{2}{*}{$\begin{array}{l}\text { Serum sensitivity } \\
(\% \text { change in c.f.u. })\end{array}$} \\
\hline & $\begin{array}{l}\log \mathrm{LD}_{50} \\
\quad \pm \mathrm{SD}\end{array}$ & $\begin{array}{l}d^{*} \\
\pm \mathrm{SD}\end{array}$ & $P+$ & $\begin{array}{l}\text { No. of } \\
\text { expts }\end{array}$ & \\
\hline PAOl & $1.2 \pm 0.7$ & - & - & 17 & +3 \\
\hline $\mathrm{PAO} 1(\mathrm{R} 68.45)$ & $4 \cdot 1 \pm 0 \cdot 5$ & $2 \cdot 2 \pm 1 \cdot 0$ & $<0 \cdot 01$ & 6 & -39 \\
\hline PAOI (R68) & $3.9-2$ & $2 \cdot 6$ & - & 1 & -30 \\
\hline PAOl(RP1) & $2 \cdot 2 \pm 0 \cdot 5$ & $1 \cdot 2 \pm 0 \cdot 3$ & $<0.001$ & 5 & -45 \\
\hline PAO1(pME106) & $2 \cdot 4 \pm 1 \cdot 2$ & $1.0 \pm 0.7$ & $<0 \cdot 001$ & 11 & -41 \\
\hline PAOl(pME107) & $2.8 \pm 1.2$ & $1.4 \pm 0.4$ & $<0.001$ & 7 & -41 \\
\hline $\mathrm{PAOl}(\mathrm{pME} 140)$ & $4 \cdot 3 \pm 1 \cdot 1$ & $1 \cdot 4 \pm 0.3$ & $<0 \cdot 01$ & 4 & -43 \\
\hline PAOlc $\ddagger$ & $3.5 \pm 1.7$ & $0.2 \pm 0.5$ & $>0 \cdot 1$ & 2 & +5 \\
\hline
\end{tabular}

* $d$ is the difference in $\log _{10} \mathrm{LD}_{50}$ between the plasmid-containing strain and PAOl in a parallel experiment. In all experiments PAOI was included as a control to account for the natural variation in the animals' susceptibility to infection.

$+P$ value for difference in $\mathrm{LD}_{50}$ between PAOl(R68.45) and PAOl(RP1) <0.05; and for difference between PAOl(R68.45) and PAO1(pME106) <0.001.

+ The $\mathrm{LD}_{50}$ values for the control (PAO1) and plasmid strains were higher in the two experiments involving PAOlc than in the other 15 experiments.

such gross effects, the $\mathrm{R}$ plasmids might be responsible for changes of the bacterial surface and this might lead to decreased virulence and serum resistance of strain PAO. Therefore, three R68 derivatives having deletions in their transfer gene regions Tra-1 or Tra-2 (Haas \& Riess, 1983) were examined; the Tra-2 region includes the surface exclusion determinant(s) (Barth, 1979). However, the plasmids pME106 and pME107 ( $\Delta[\mathrm{Km}$ Tra-1]; surface exclusion positive) and pME140 ( $\Delta[\mathrm{Km}$ Tra-2]; surface exclusion negative) still conferred serum sensitivity on strain PAO1 and virulence was not restored (Table 1).

All plasmids except pME140 were stable in strain PAO propagated in the mouse. Mice infected with PAOl(pME140) showed a mixture of carbenicillin-resistant and sensitive colonies in cultures from the peritoneal cavity. Thus, the decrease in virulence caused by this plasmid is probably underestimated (Table 1). Slight instability of pME130 was also observed in broth cultures; after approximately 60 generations in NYB without antibiotic selection $6-12 \%$ of the PAO1 cells had lost the plasmid. The $14.5 \mathrm{~kb}$ deletion of pME140, which spans the Tra- 2 region and the kanamycin resistance gene (Haas \& Riess, 1983), also removes a site that seems to be required for the resolution of plasmid multimers to monomers; deletion of this site leads to plasmid instability in Escherichia coli (Grinter, 1985). The Tra-1 deletions of pME106 and pME107, by contrast, did not cause any plasmid instability in $P$. aeruginosa during 60 generations.

The effect of IncP-1 plasmids on virulence is probably not restricted to strain PAO, since similar findings have been reported for plasmid RP1 in other Pseudomonas strains (Wright et al., 1977; McManus et al., 1981). Plasmid FP39 (Pemberton \& Holloway, 1973; unclassified incompatibility group) caused a 100 -fold decrease in virulence for $P$. aeruginosa PAO in the mouse burn model (B. Wretlind, unpublished data).

No evidence could be obtained for a direct involvement of the determinant specifying resistance to kanamycin because deletion of these genes did not lead to full serum resistance or virulence (Table 1). Also, RP1 derivatives having deletions in their tetracycline or carbenicillin resistance genes still caused serum sensitivity (data not shown). In conclusion, the decrease in serum resistance and virulence of $P$. aeruginosa caused by the IncP-1 R plasmids could not be attributed to gross effects on growth rate, motility, or to a single factor such as tra genedependent alterations of the bacterial surface.

This work was supported by the Research Institute of the Swedish National Defence (grant to B. W.). D.H. gratefully acknowledges the excellent technical assistance provided by K. Koch. 


\section{REFERENCES}

BARTH, P. T. (1979). RP4 and R300B as wide hostrange plasmid cloning vehicles. In Plasmids of Medical, Enitronmental and Commerical Importance, pp. 399-410. Edited by K. N. Timmis \& A. Pühler. Amsterdam: Elsevier/North-Holland.

Binns, M. M., Mayden, J. \& Levine, R. B. (1982). Further characterization of complement resistance conferred on Escherichia coli by the plasmid genes traT of RI00 and iss of ColV, I-K94. Infection and Immunity 34, 654-659.

Burkardi, H.-J., Riess, G. \& PÜhler, A. (1979). Relationship of group $\mathrm{Pl}$ plasmids revealed by heteroduplex experiments: RP1, RP4, R68 and RK2 are identical. Journal of General Microbiology 114, 341-348.

Caruso, M. \& Shapiro, J. A. (1982). Interactions of Tn 7 and temperate phage Fl16L of Pseudomonas aeruginosa. Molecular and General Genetics 188, 292 298.

Clark, R. B., Janda, J. M. \& Bottone, E. J. (1984). Phenotypic properties correlated with the absence of virulence among gentamicin-resistant Pseudomonas aeruginosa strains. Journal of Clinical Microbiology. 20, 235-238.

Currier, T. C. \& Morgan, M. K. (1981). Restriction endonuclease analysis of the incompatibility group P-I plasmids RK2, RPI, RP4, R68 and R68.45. Current Microbiology 5, 323-327.

Daum, R. S., Syriopoulou, V. P., Smith, A. L., SCHEIfEle, D. W. \& Willard, J. E. (1981). Loss of plasmid DNA coding for $\beta$-lactamase during experimental infection with Haemophilus influenzae type b. Journal of Infectious Diseases 143, 548-553.

Elwell, L. P. \& Shipley, P. L. (1980). Plasmidmediated factors associated with virulence of bacteria to animals. Annual Review of Microbiology 34, 465-496.

FINNEY, D. J. (1964). The Spearman-Kärber method. In Statistical Methods in Biological Assays, 2nd edn, pp. 524-530. London: Charles Griffin.

Grinsted, J., SAunders, J. R., INGRAm, L. C., Sykes, R. B. \& Richmond,'M. H. (1972). Properties of an Rfactor which originated in Pseudomonas aeruginosa 1822. Journal of Bacteriology 110, 529-537.

Grinter, N. J. (1985). Plasmid stability: involvement of a plasmid-coded primase and site-specific recombination/resolution systems. In Plasmids in Bacteria, p. 858 . Edited by D. Helinski, S. N. Cohen, D. Clewell, D. Jackson \& A. Hollaender. New York: Plenum Press.

HaAS, D. \& Holloway, B. W. (1976). R factor variants with enhanced sex factor activity in Pseudomonas aeruginosa. Molecular and General Genetics 144, 243 251.

HaAs, D. \& RiEss, G. (1983). Spontaneous deletions of the chromosome-mobilizing plasmid R68.45 in Pseudomonas aeruginosa PAO. Plasmid 9, 42-52.

Khakoo, R. A. \& Kluge, R. M. (1978). Decreased virulence of gentamicin-resistant strains of Pseudomonas aeruginosa in a rat model. Journal of Laboratory and Clinical Medicine 91, 96-103.

Klemperer, R. M. M., Ismail, N. T. A. J. \& Brown, M. R. W. (1979). Effect of R plasmid RPI on the nutritional requirements of Escherichia coli in batch culture. Journal of General Microbiology 115, 325 331 .

LACEY, R. W. (1975). A critical appraisal of the importance of R-factors in the Enterobacteriaceae in viro. Journal of Antimicrobial Chemotherapy 1. 25-37.

LiU, P. V. (1973). Exotoxins of Pseudomonas aeruginosa. 1. Factors that influence the production of exotoxin A. Journal of Infectious Diseases 128, 506513.

Lowbury, E. J. L., Kidson, A., Lilly, H. A., Ayliffe, G. A. J. \& Jones, R. J. (1969). Sensitivity of Pseudomonas aeruginosa to antibiotics: emergence of strains highly resistant to carbenicillin. Lancet ii, 448-452.

McManus, A. T., Northam. W. J. \& MoOdy, E. E. M. (1981). Suppression of Pseudomonas aeruginosa burn surface infection by plasmid RP1. Abstracts of the Annual Meeting of the American Society for Microbiologl, Abstract B15.

PAvlovskis, O. R. \& WRETLIND, B. (1979). Assessment of protease (elastase) as a Pseudomonas aeruginosa virulence factor in experimental mouse burn infection. Infection and Immunity 24, 181-187.

Pavlovskis, O. R., Yaffe, L. J., Wretlind, B. \& Galloway, D. R. (1983). Experimental Pseudomonas aeruginosa infections in burned mice and rats: description of a model. In Experimental Bacterial and Parasitic Infections, pp. 103-108. Edited by G. Keusch \& T. Wadström. New York: Elsevier.

Pemberton, J. M. \& Holloway, B. W. (1973). A new sex factor of Pseudomonas aeruginosa. Genetical Research 21, 263-272.

Smith, H. R., Scotland, S. M. \& Rowe, B. (1983). Plasmids that code for production of colonization factor antigen II and enterotoxin production in strains of Escherichia coli. Infection and Immunity 40, 1236-1239.

Stanisich, V. A. \& Holloway, B. W. (1971). Chromosome transfer in Pseudomonas aeruginosa mediated by R factors. Genetical Research 17, 169 172.

Stieritz, D. D. \& HolḍeR, I. A. (1975). Experimental studies of the pathogenesis of infections due to Pseudomonas aeruginosa: description of a burned mouse model. Journal of Infectious Diseases 131, 688 691.

Thomassen, M. J. \& Demko, C. A. (1981). Serum bactericidal effect on Pseudomonas aeruginosa isolates from cystic fibrosis patients. Infection and Immunity 33, 512-518.

Willetts, N. S., Crowther, C. \& Holloway, B. W (1981). The insertion sequence IS21 of R68.45 and the molecular basis for mobilization of the bacterial chromosome. Plasmid 6, 30-52.

Williams, P. H. (1979). Novel iron uptake system specified by ColV plasmids: an important component in the virulence of invasive strains of Escherichia coli. Infection and Immunity 26, 925-932.

Wright, B. L., Carrick, L., JR \& Jollick, J. D. (1977). The effect of an R-factor on the virulence of Pseudomonas aeruginosa in the mouse. Abstracts of the Annual Meeting of the American Society for Microbiology, Abstract B117. 